\title{
KAJIAN KONSEP TEORI LIMA ELEMEN CITRA KOTA PADA KAWASAN KOTA TUA JAKARTA
}

\author{
Muhammad Akbar Rafsyanjani*1, Ari Widyati Purwantiasning ${ }^{2}$ \\ Arsitektur, Universitas Muhammadiyah Jakarta ${ }^{1,2}$ \\ *1akbar.arch98@gmail.com,2arwityas@yahoo.com
}

\begin{abstract}
Abstrak_Ketika kita bicara tentang kawasan kota kita perlu membahas tentang manusia yang berada di dalamnya, dikarenakan banyak sekali ketika kita memikirkan kawasan kota tidak banyak dari mereka yang memperlihatkan dari sisi mikronya yaitu manusia Maka dari itu, penelitian ini mempermasalahkan bagaimana penerapan prinsip teori lima elemen citra kota pada Kawasan Kota Tua Jakarta, kemudian bagaimana mengkaji teori lima elemen citra kota pada Kawasan Kota Tua Jakarta. Dari permasalahan muncul tujuan dari penelitian ini dapat menjelaskan penerapan prinsip lima elemen citra kota pada Kawasan Kota Tua Jakarta. Adapun hasil yang ingin dicapai dari penelitian ini adalah dengan menjelaskan path, edges, node, district, dan landmark dari Kawasan Kota Tua Jakarta. Hasil yang didapat dari penelitian ini terhadap Kawasan Kota Tua Jakarta adalah Path di dalam kawasan ini ditunjukkan dengan jalur kendaraan, kereta api, sungai, pedestrian, kemudian Edges di dalam kawasan ini ditunjukkan dengan batasan sungai yang membatasi antara zona inti dan zona penunjang, kemudian node di dalam kawasan ini ditunjukkan dengan persimpangan jalan yang terhubung ke kawasan zona inti Kota Tua Jakarta, kemudian district di dalam kawasan ini ditunjukkan dengan kawasan inti dan penunjang sebagai pembeda antara distrik satu dengan yang lainnya, kemudian di dalam kawasan ini ditunjukkan dengan Museum Fatahillah.
\end{abstract}

Kata kunci: Lima Elemen; Kevin Lynch; Kawasan Kota Tua Jakarta

\begin{abstract}
When we talk about the city area we need to talk about the human being in it, because there are so many things when we think that the city is not many of them that show from the side of the Micronics man, therefore, This study disputed how to apply the theory principle of five elements of the city image in the Old City area of Jakarta, then how to examine the five elements of the city image element in the Old City area of Jakarta. From the problem arising, the purpose of this research can explain the application of the principle of five components of city image in the Old City area Jakarta. The result of this research is to describe the path, edges, nodes, district, and landmarks of the Old City area of Jakarta. The result of this research on Jakarta's Old City area is Path within this region indicated by vehicle, railway, river, pedestrian, then Edges within this area are characterized by river boundary limiting Between the core zone and the supporting zone, then the nodes within this area are indicated by a crossroads connected to the core zone area of the old City of Jakarta, then district within this area is indicated by the core region and support as Differentiator between District One and another, then within this area is characterized by Fatahillah Museum.
\end{abstract}

Keywords: Five Elements; Kevin Lynch; Jakarta Old Town Area.

\footnotetext{
${ }^{1}$ Arsitektur Universitas Muhammadiyah Jakarta

${ }^{2}$ Arsitektur Universitas Muhammadiyah Jakarta
} 


\section{PENDAHULUAN}

Negara Kesatuan Republik Indonesia adalah sebagai Negara yang mempunyai makna tradisional dan modern pada saat ini. Akan tetapi Indonesia sebagai salah satu Negara yang mempunyai keanekaragaman suku, budaya, dan ras yang tidak dimiliki oleh kawasan pada umumnya. Kawasan kota harus memiliki karakteristik yang mempunyai latar belakang kotanya, namun kawasan kota tidak terlepas dari sejarah kota yang dulunya digunakan oleh para pendiri kawasan kota itu sendiri.

Ketika kita berbicara tentang kawasan kota kita perlu juga membahas tentang manusia yang berada didalamnya, dikarenakan banyak sekali ketika kita memikirkan kawasan kota itu sendiri, tetapi tidak banyak yang memperlihatkan dari sisi mikronya yaitu manusia. Kawasan kota pada umumnya manusia sebagai salah satu yang berpengaruh terhadap perkembangan dan pertumbuhan itu sendiri.

Kawasan adalah sebuah tempat yang mempunyai bagian-bagian penting dimana tempat ini untuk menampung kegiatan manusia berdasarkan kebutuhan-kebutuhannya masing-masing.Pada setiap tempat juga memiliki keanekaragaman yang berbeda-beda yang menunjukkan identitas dari kawasan itu sendiri untuk melancarkan segala hal yang berhubungan dengan kegiatannya.Kawasan dikelompokkan menjadi kawasan permukiman, perkantoran, industri, area hijau, wisata, dan sebagainya (A. W. Purwantiasning et al, 2013).

Maka dari itu penelitian ini membahas tentang lima elemen citra kota yang terdapat di dalam kutipan buku Image of The City. Identitas kota adalah citra mental yang terbentuk dari ritme biologis tempat dan ruang yang tumbuh di dalam tubuh yang selalu mengakar oleh social, ekonomi, budaya masyarakat kota itu sendiri (Chapman \& Lynch, 1962).

Dari latar belakang ini akan dijabarkan permasalahan-permasalahan yang timbul di dalam penelitian mengenai teori lima elemen citra kota pada kawasan kota bersejarah. Namun menjadi pertanyaan di dalam penelitian ini, bagaimana penerapan konsep teori lima elemen citra kota pada Kawasan Kota Tua Jakarta. Bagaimana mengkaji teori lima elemen citra kota menurut Kevin Lynch?. Bagaimana prinsip-prinsip lima elemen citra kota dalam Kawasan Kota Tua Jakarta?.Penelitian ini mempunyai tujuan yaitu untuk menjelaskan bagaimana penerapan Kawasan Kota Tua Jakarta dengan teori lima elemen citra kota menurut Kevin Lynch, kemudian untuk mengkaji teori lima elemen citra kota menurut Kevin Lynch, serta dapat menjelaskan prinsip prinsip teori lima elemen citra kota menurut Kevin Lynch terhadap Kawasan Kota Tua Jakarta.

\section{METODE PENELITIAN}

Metode penelitian deskriptif kualitatif ini digunakan dalam penelitian kali ini.Jenis metode ini yang tujuannya untuk pengumpulan data dilakukan dengan survey primer berupa observasi lapangan, wawancara, studi pustaka, dan dokumentasi gambar lengkap dan survey sekunder dengan melakukan studi literatur. Dengan dapat mengetahui bagaimana Kawasan Kota Tua Jakarta menggunakan prinsip-prinsip lima elemen citra kota. Penelitian ini berlokasi di Kawasan Kota Tua Jakarta atau bagian zona inti dari kawasan wisata Kota Tua Jakarta. Waktu penelitian Penelitian kali ini dilakukan pada bulan Oktober pada tanggal 7 sampai dengan 25 Oktober 2019 dengan jangka survey lokasi kawasan Kota Tua Jakarta.Penelitian ini dilakukan dengan pembagian waktu 
secara efisien dan dilakukan pencaharian data existing lapangan, foto kemudian mengamati area sekitar kawasan tersebut.

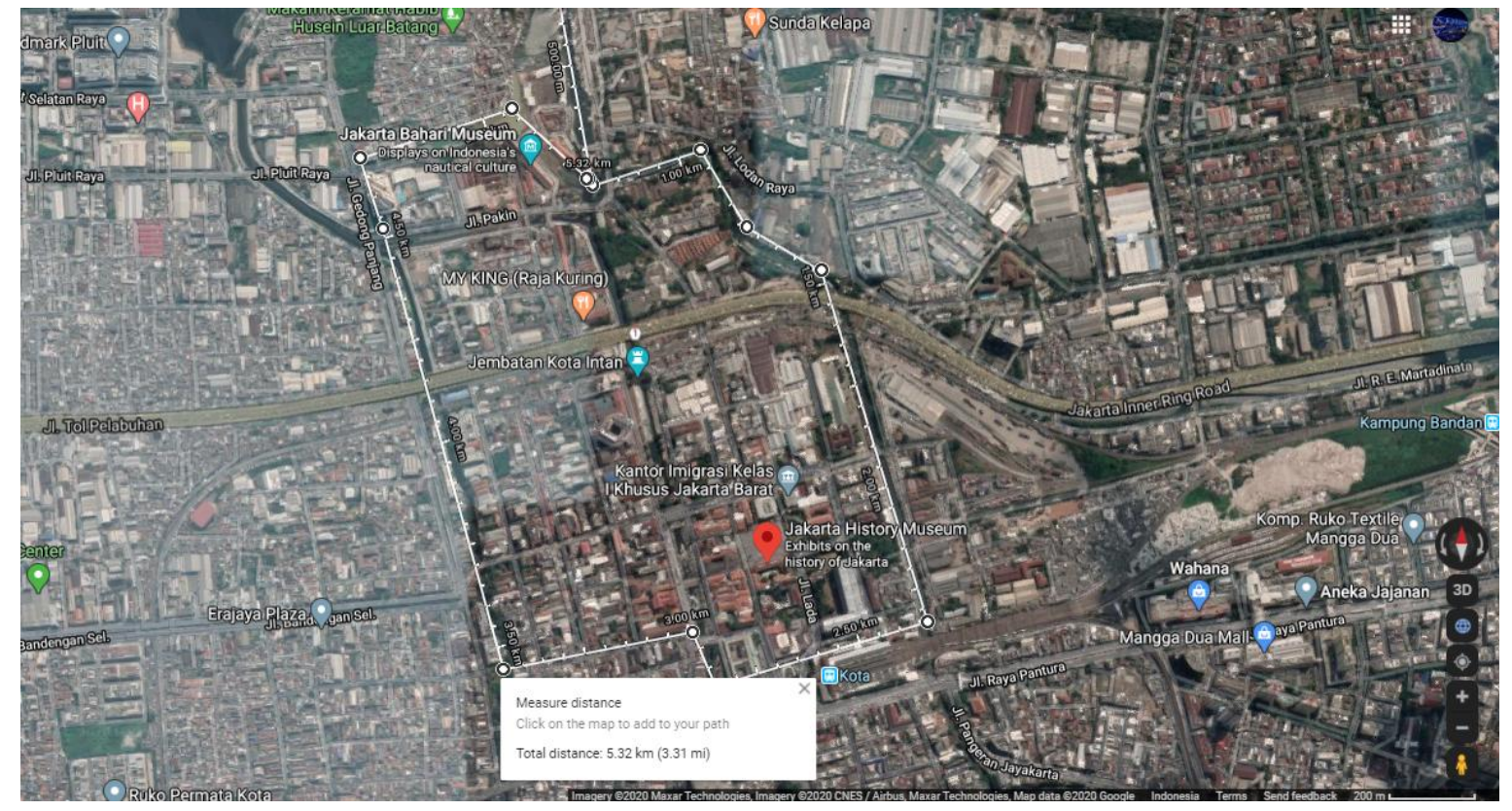

Gambar 1. Peta Lokasi Penelitian di Kawasan Kota Tua Jakarta

Sumber Peta : Digitalisasi Peneliti, Berbasis Google Maps, 2020

Materi penelitian menggunakan teori 5 elemen citra kota yang memiliki keterkaitan dengan teori lima elemen citra kota yang dijelaskan oleh Kevin Lynch, adapun citra kota yang digunakan adalah path, edges, nodes, district, landmark.

Analisis data pada penelitian ini dilakukan dengan menggunakan metode berpikir deduktif.Berpikir deduktif adalah menarik kesimpulan dari pernyataan umum menjadi pernyataan yang lebih spesifik (Nugrahani et al, 2008).Metode ini sesuai dengan bentuk metode penelitian deskriptif kualitatif. Analisis data digunakan untuk menjawab permasalahan penelitian sehingga dapat mencapai tujuan penelitian yang sudah dijabarkan. Analisis data pada penelitian ini dilakukan dengan cara sebagai berikut :

1. Pengumpulan data, kemudian data-data yang didapatkan dikategorikan/ dipisahkan sesuai dengan teori lima elemen citra kota pada Kawasan Kota Tua Jakarta

2. Penyajian data, data yang ada dikumpulkan seperti data path, edges, node, district, dan landmark maupun data-data yang berhubungan dengan data fisik, batasan wilayah, dan dokumentasi di Kawasan Kota Tua Jakarta

3. Data keseluruhan diambil benang merahnya yang menjadikan sebuah kesimpulan yang dijabarkan dengan mengaitkan teori lima elemen citra kota pada Kawasan Kota Tua Jakarta.

\section{HASIL DAN PEMBAHASAN}

Berdasarkan hasil observasi lapangan dan wawancara didapatkan hasil dan pembahasan pada Kawasan Kota Tua Jakarta dengan hasil pembahasan berkaitan dengan 5 elemen citra kota yaitu path, edges, node, district, dan landmark sebagai berikut :

1. Analisis Path (Jalur) pada Kawasan Kota Tua Jakarta

Jalur pada Kawasan Kota Tua Jakarta terdapat jalur kereta api, jalur kendaraan, jalur sungai dan pedestrian. Namun jalur yang dianalisis yaitu jalur yang termasuk ke dalam 
penggunaan dalam masa lalu/ jalur yang sudah ada sejak lama yang digunakan sebagai jalur cagar budaya dikarenakan pembahasannya akan ke kota bersejarah. Jalur pada Kawasan Kota Tua Jakarta masuk ke dalam teori Kevin Lynch dikarenakan mempunyai semua jenis jalur yang menghubungkan setiap blok bangunan, namun sedikit berbeda dengan jalur yang dahulu. Jalur yang dulu memotong kawasan inti yang terdapat di dalam Kawasan Wisata Kota Tua Jakarta.

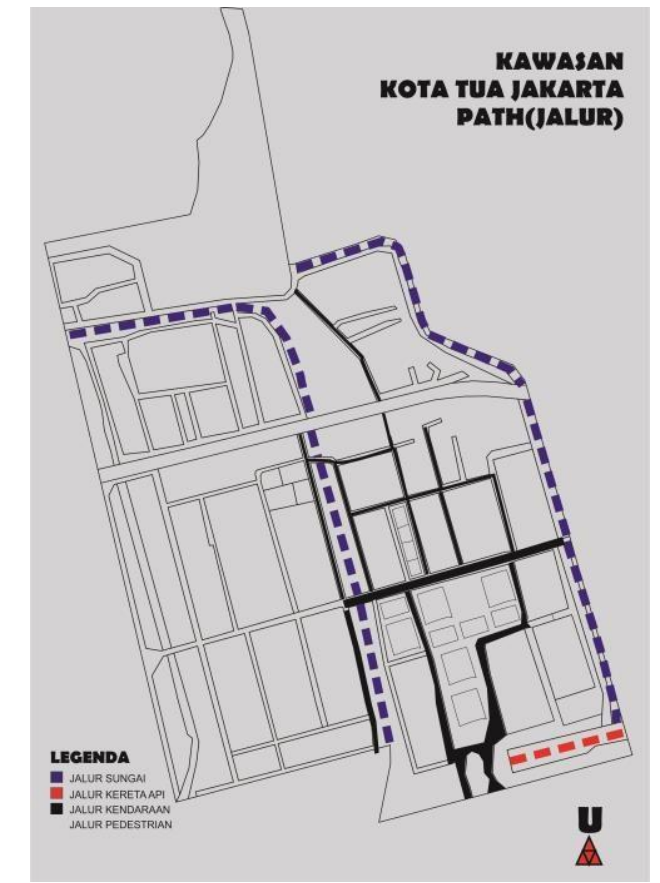

Gambar 2. Jalur Kawasan Zona Inti Kota Tua Jakarta Sumber Peta : Peneliti, 2019

Maka dari itu jalur yang berada di Kawasan Kota Tua Jakarta ini lebih dominan untuk area publik dengan di kelilingi oleh jalur-jalur yang lainnya dan Kawasan Kota Tua Jakarta ini mempunyai ruang publik di tengah-tengah bangunan yang berada di kawasan ini.

2. Analisis Edges (Batasan) pada Kawasan Kota Tua Jakarta

Batasan pada Kawasan Kota Tua Jakarta terdapat banyak batasan-batasan yang memiliki zona tersendiri, yaitu adanya zona inti, zona penunjang, zona tembok dalam dan tembok luar, namun di kawasan ini juga batasan wilayahnya dibatasi dengan jembatan atau protal yang membedakan zona satu dengan zona yang lainnya. Batasan ini berpengaruh kepada seberapa penting wilayah itu dengan wilayah yang lain. Dijelaskan dalam gambar di bawah ini.

Batasan ini terdapat banyak sekali portal-portal atau jembatan yang membedakan zona inti dengan zona yang lain, terlebih daripada itu zona lain juga termasuk kedalam Kawasan Kota Tua Jakarta hanya saja zona lain tidak menjajakan bangunan sejarah yang termasuk ke dalam bangunan yang dikonservasikan. 


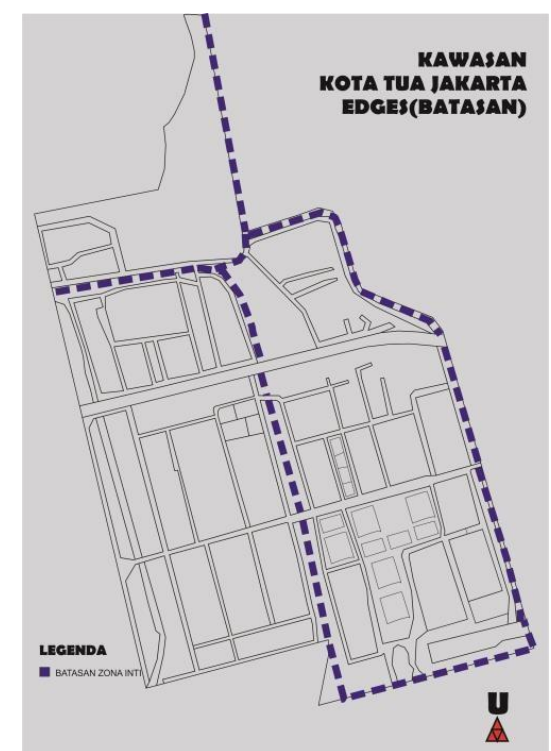

Gambar 3. Batasan Wilayah Zona Inti Kawasan Kota Tua Jakarta Sumber Peta : Peneliti, 2019

3. Analisis Node (Persimpangan) pada Kawasan Kota Tua Jakarta

Persimpangan pada Kawasan Kota Tua Jakarta ini terdapat ke dalam persimpangan yang bersejarah yang dahulunya digunakan sebagai media jalan. Namun tak hanya persimpangan jalan saja, sebuah Alun-Alun juga termasuk ke dalam titik pertemuan antara jalan satu dengan jalan yang lain. Dapat dilihat pada gambar 4, terdapat titik-titik persimpangan maupun titik pertemuan di dalam Kawasan Kota Tua Jakarta. Titik pertemuan ini termasuk ke dalam titik pertemuan yang dijelaskan di dalam teori kawasan bersejarah.

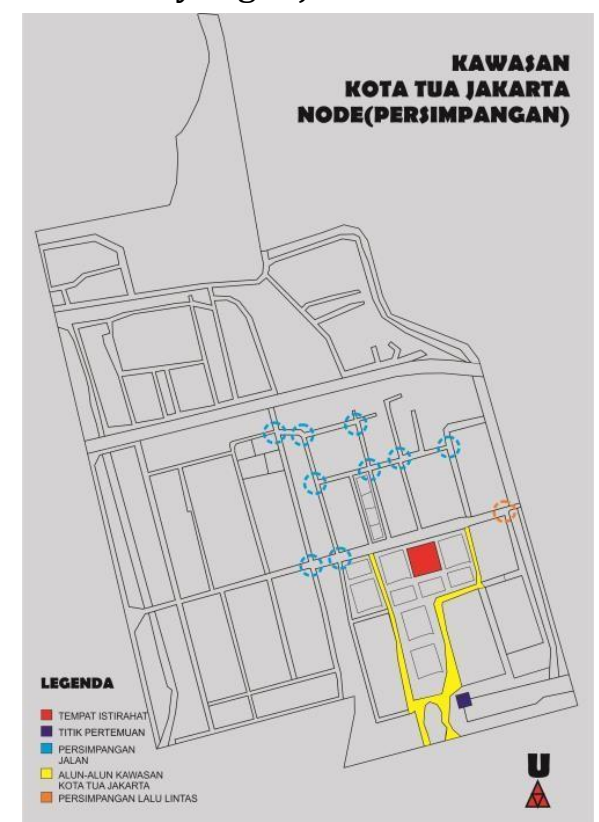

Gambar 4. Persimpangan Kawasan Kota Tua Jakarta Sumber Peta : Peneliti, 2019

4. Analisis Distrik (District) pada Kawasan Kota Tua Jakarta

Menurut Kevin Lynch, district merupakan wilayah yang memiliki kesamaan (homogen). Kesamaan tadi bisa berupa kesamaan karakter/ ciri bangunan secara fisik, fungsi 
wilayah, latar belakang sejarah dan sebagainya. Sebuah kawasan district memiliki ciri khas yang mirip (bentuk, pola, wujudnya) dan khas pula dalam batasnya, dimana orang merasa harus mengakhiri atau memulainya.

Distrik pada Kawasan Kota Tua Jakarta ada banyak distrik sehingga berdasarkan pada gambar 5 menjelaskan distrik yang paling inti dari distrik-distrik yang lain adalah bagian zona inti dikarenakan zona inti ini yang sudah termasuk ke dalam kawasan bersejarah.

Maka dari itu, Kawasan Kota Tua Jakarta distriknya termasuk ke dalam zona konservasi dan berbentuk zona memutar dengan memutarkan distrik inti di wilayah Kawasan Kota Tua Jakarta.

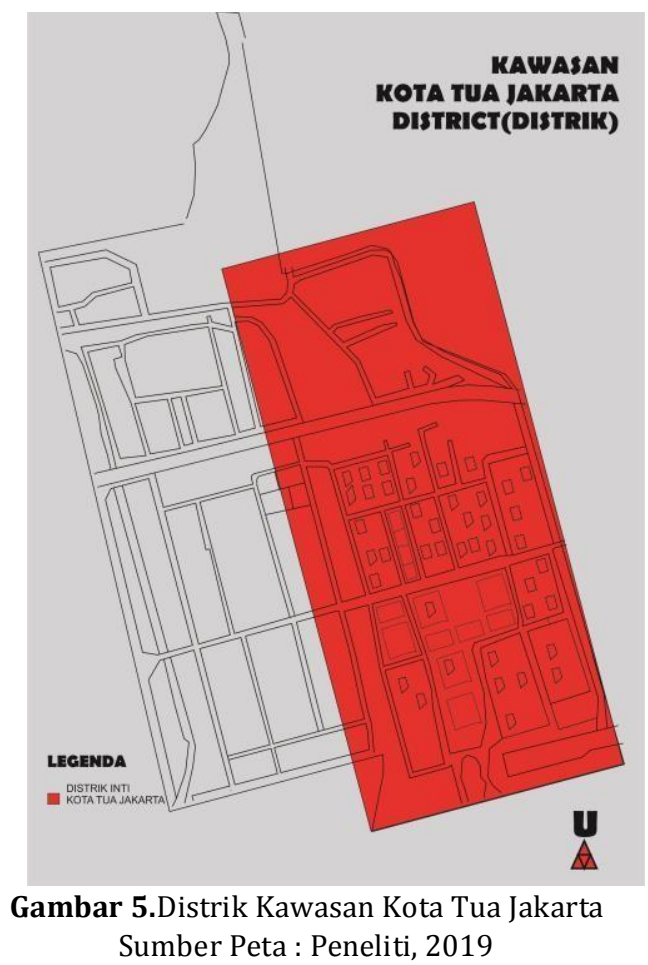

5. Analisis Landmark (Penanda) pada Kawasan Kota Tua Jakarta

Landmark adalah titik acuan dimana si pengamat tidak memasukinya, elemen ini adalah berada dititik kawasan luar dan bisa juga di dalam sebuah tapak. Landmark merupakan titik referensi seperti hal node, tetapi nodes ini tidak bisa dimasuki oleh orang dikarenakan node bisa dilihat dari luar. Landmark biasanya berupa benda fisik yang didefinisikan dengan sederhana seperti: bangunan, tanda, toko atau pegunungan. 


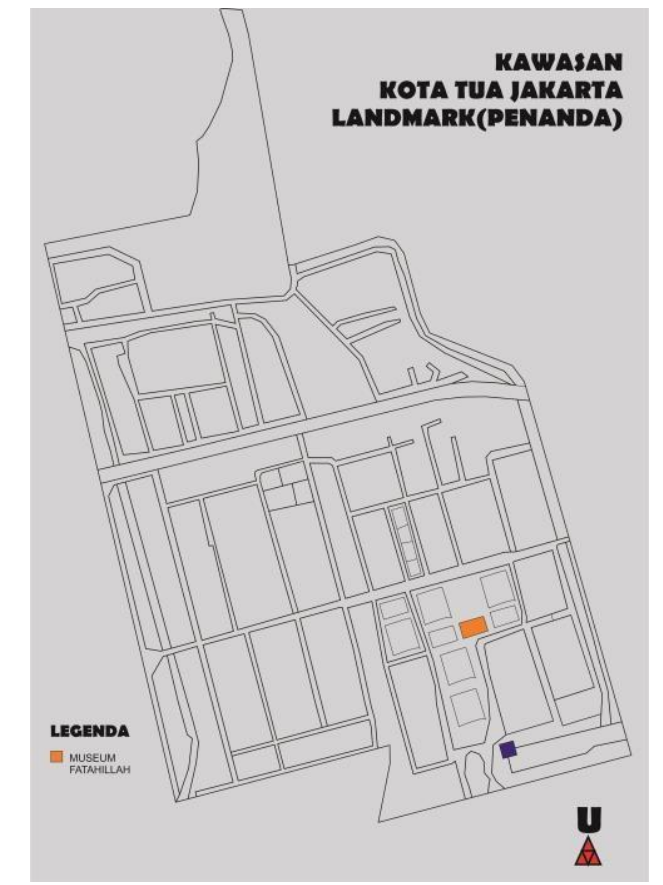

Gambar 6. Landmark pada Kawasan Kota Tua Jakarta Sumber : Peneliti, 2019

Penanda pada Kawasan Kota Tua Jakarta adalah Museum Fatahillah dikarenakan Museum Fatahillah ini termasuk ke dalam kategori bangunan bersejarah yang grade A. Maksud dari grade A adalah bangunan sejarah yang tidak diperbolehkan untuk dibongkar ataupun diubah bentuknya dan juga Museum Fatahillah ini masuk ke dalam bangunan yang lebih 50 tahun berdiri di Kawasan tersebut.

\section{KESIMPULAN}

Berdasarkan rumusan masalah pada penelitian yang telah dilakukan, maka dapat diperoleh kesimpulan sebagai berikut: Dalam mengkaji tentang Teori Kevin Lynch tentang lima elemen citra kota pada Kawasan Kota Tua Jakarta adalah dengan mengkaji teori-teori yang digunakan oleh Kevin Lynch. Penjelasan mengenai teori lima elemen citra kota adalah teori yang menjadikan sebuah kota dalam bentuk yang nyata sehingga dapat diketahui identitas dari sebuah kota tersebut, namun bukan hanya untuk identitas kota teori ini menjelaskan ciri khas dari wilayah tersebut. Prinsip-prinsip yang didapatkan pada teori lima elemen citra kota menurut Kevin Lynch dari buku Image Of The City adalah Path, Edges, Node, District, Landmark. Kawasan kota bersejarah merupakan kawasan yang mempunyai khas setiap masing-masing kawasan bersejarah. Secara umum kawasan kota bersejarah memiliki sejumlah bangunan khusus yang dilestarikan di dalam kawasan tersebut, kemudian kawasan kota bersejarah juga harus memiliki kualitas bangunan yang masih kokoh dari masa dahulu hingga masa sekarang dan jalur-jalur yang masih digunakan sampai sekarang, Penerapan lima elemen citra kota pada Kawasan Kota Tua Jakarta yang telah dikaji bertuliskan benang merah dari masing-masing studi kasus pada kawasan kota bersejarah. 
1. Path di dalam Kawasan Kota Tua Jakarta biasanya jalur yang sering digunakan dan terhubung langsung ke kawasan bersejarah tersebut.

2. Edges di dalam Kawasan Kota Tua Jakarta biasanya batasan yang dijelaskan dalam bentuk seperti sungai, jembatan.

3. Node di dalam Kawasan Kota Tua Jakarta biasanya titik perkumpulan, titik pertemuan maupun persimpangan jalan yang paling digunakan sampai sekarang.

4. District di dalam kawasan kota bersejarah biasanya dapat dilihat dari latar belakang dari setiap kawasan tersebut. Dikarenakan dari latar belakang dapat membentuk distrik dengan sendirinya dari kawasan tersebut.

5. Landmark di dalam setiap kawasan adalah bangunan yang bisa dijadikan landmark mencirikan bangunan sebagai penanda/identitas dari kawasan kota bersejarah dan mengaitkan dengan konservasi dengan adanya kategori-kategori yang dapat menentukan bangunan tersebut. Pada Kawasan Kota Tua Jakarta ditandai dengan bangunan Museum Fatahillah.

\section{DAFTAR REFERENSI}

Chapman, E. H., \& Lynch, K. (1962).The Image of the City. In The Journal of Aesthetics and Art Criticism

(Vol. 21). https://doi.org/10.2307/427643

DPR.(2010). Undang-Undang Nomor 11 Tahun 2010.

Firdaus, F., Purwantiasning, A. W., \& Prayogi, L. (2018). Revitalisasi Kawasan Kota Tua Jakarta Dengan Alternatif Konsep TOD. Purwarupa Jurnal Arsitektur, 2(1), 35-44.

Kawulusan, M. (2017).Perancangan Public Landmark Pada Ruang Terbuka Publik.14(3), 39-51.

Nugroho, C. A., Purwantiasning, A. W., \& Hantono, D. (2017).Penerapan Teori Linkage Dalam Penataan Kawasan Wisata Pusaka Soekarno Di Blitar.Purwarupa, 1(2), 29-34. Retrieved from https://jurnal.umj.ac.id/index.php/purwarupa/article/view/2829/2238

Pettricia, H. A., \& Wardhani, D. K. (2014).Di Pusat Kota Malang.12(1), 10-23.

Purwantiasning, A. W., \& Kurniawan, K. R. (2017).Kota Pusaka dan Pemikiran Kembali tentang Historical Attachment dalam Persepsi Masyarakat Studi Kasus: Parakan, Temanggung. (December 2018), C137C144. https://doi.org/10.32315/sem.1.c137

Purwantiasning, A. W., Masruroh, F., \& Nurhidayah. (2013). Analisa kawasan boat quay berdasarkan teori kevin lynch. NALARs, 12(1), 59-72.

Purwantiasning, B. (2019). Historical Attachment Of Colonial Building Through Community Perception : Case Study Of Museum Fatahillah, Kota Lama, Jakarta.14 (Spesial Issue), 166 to 175. https://doi.org/10.21163/GT

Saputra, H., Purwantiasning, A. W., Arsitektur, J., \& Muhammadiyah, U. (2013). Kajian Konsep Adaptive Reuse Sebagai Alternatif.45-52.

Theresiana, E., \& Dewi, S. P. (2013).Kampung Kauman Kota Semarang. 2(3), 851-862. 